\title{
A Model of An Integration System for Operations and Cost Data Designed to Control Logistics Processes in Agricultural Enterprises
}

\author{
Karol Wajszczuk', Jacek Wawrzynowicz², Bogusław Śliwczyński
}

\begin{abstract}
The paper presents a model of an integration system for operations and cost data designed for the needs of process controlling in agricultural enterprises, with special emphasis on logistics processes. The proposed model constituted the basis for the development of an IT tool to be used in the identification and analysis of logistics costs in agricultural enterprises in terms of the process based approach. As a result of research and programming efforts a model was developed, which made it possible in agricultural enterprises to determine the type-based relationship of cost dynamics and structure with realized actions, operating processes (including logistics processes) and products, as well as the relationship of these costs with used resources, maintained stocks, applied materials and work methods. Moreover, this model facilitates cost allocation to products and processes as well as cost centers and points, and makes it possible to determine multidimensional dependencies of the result (divided into individual products) on incurred costs.
\end{abstract}

Key words: operating costs, logistics costs, management accounting, process analysis, controlling, agricultural enterprises

\section{JEL Classification: M21, M41, Q10}

${ }^{1}$ Poznan University of Life Sciences, Poland

2 Poznan University of Life Sciences, Poland

${ }^{3}$ Institute of Logistics and Warehousing in Poznan, Poland

\section{Introduction}

In enterprises of many economic sectors operational costs of the complete product supply chain, e.g. procurement and materials management, production, distribution (including warehousing, forwarding and transport), make up a considerable (above 70\%) share of total running costs (Kaplan and Cooper, 1988; Rzymyszkiewicz, 1995; Pfohl, 1998; Skowronek and Sarjusz-Wolski, 2007).

Agricultural enterprises belong to a group of enterprises which are characterized by a high share of operat-

Corespondence concerning to this article should be addressed to:wajszczuk@up.poznan.pl ing costs in total production costs. Based on conducted investigations it was found that the ratio of these costs is around 70\% - 85\% (Wajszczuk and Wielicki, 2004).

Agricultural enterprises, similarly as many other enterprises in Poland, after the economic and political transformations of 1989 started to operate within the framework of market economy, adopting its principles. This transformation from a centrally planned economy to a free market economy has been a difficult and complex process and the rate of these transformations depends, among other things, on the type and level of resources available for a given enterprise. In comparison to enterprises of other sectors, in agricultural enterprises this process has been slow. Thus con- 
siderable delays are observed in the transformations, e.g. in management, the application of controlling in management decision aiding processes (Horvath, 1990; Vollmuth, 1995), adaptation of infrastructure to flexible management of agricultural produce supply chains, and particularly IT infrastructure.

On average in enterprises of different sectors logistics costs constitute such a high proportion of total running costs (on average 20 - 30\%) that fundamental re-designing of logistics processes may become a major element in cost reduction within an enterprise (Pfohl, 1998; Skowronek and Sarjusz-Wolski, 2007).

It results from earlier studies on agricultural enterprises that - depending on the type of activity and level of intensity - from 20 to 80 ton of load are transported per hectare of agriculturally utilized area (Wajszczuk, 1994; Wielicki, 1983). Thus, already in 1913 Albrecht Thaer aptly stated that "a farm is involuntarily a transport company" (Wolszczan, 1988). This is manifested in the high share of logistics costs in total production costs, amounting to $35 \%$ - 42\% (Wajszczuk, 2005).

Undertaking effective actions aiming at the optimization of logistics processes, which may determine the development of an enterprise and competitiveness of its products, requires on the part of the managing staff detailed analyses of efficiency for these processes, analyses of costs and result sensitivity in terms of individual cost groups, as well as having appropriate tools aiding operations management (Christopher, 2005). Such tools in- clude management accounting (feed-back) and controlling (feed-forward) oriented towards a specific strategy of an enterprise, particularly strategic management of costs, including logistics costs (Śliwczyński, 2007).

Thus, management staff of agriculture enterprises, within the framework of product cost analysis (as well as a comparison of product costs with sales volume of these products) looks for different possibilities of analyzing actions performed within such processes as e.g. procurement or agricultural production, as well as consumption of assets, being a direct cause of incurred costs.

\section{Defining the problem}

Unfortunately, the management staff of agricultural enterprises does not always have a filing-information system at their disposal, facilitating appropriate analyses and evaluations of efficiency for operational activities of the enterprise. Apart from the lack of adequate management information systems, there are also content-related obstacles to the identification, assessment of operational (process-related) cost level and structure in a complete agricultural product supply chain. Traditional cost recording (by type as presented in Table 1) and allocating them to enterprise assets (wages, depreciation, materials, energy, outsourced services, etc.) is a significant restriction to the use of a comprehensive operational (process) cost accounting system, as it is enforced by the binding Act on accounting (Nita, 2008).

Table 1. An example of organization of Chart of Accounts for group 4 - Costs by type and their allocation.

\begin{tabular}{|l|l|}
\hline Account no. & Type of cost \\
\hline 400 & Depreciation \\
\hline 401 & Consumption of materials and energy \\
\hline 402 & Transport services \\
\hline 403 & Repair services \\
\hline 404 & Other services \\
\hline 405 & Wages \\
\hline 406 & Social benefits \\
\hline 407 & Other employee compensation \\
\hline 408 & Business trips \\
\hline 409 & Taxes increasing costs \\
\hline 410 & Other costs \\
\hline
\end{tabular}


However, these methods are not adapted to allocation of costs to products and processes, which makes it difficult to analyze multidimensional dependences of a product and its competitiveness on the realized processes and consumed assets (Barney, 1991; Kaplan and Norton, 2001).

Traditional methods of product cost intensity assessment make product profitability dependent on turnover value - which means that production, distribution or sales costs are accounted for by income value base. Cost allocation proportionality means that products of a similar sales value are identically cost-consuming for an enterprise. However, such a cost account does not reflect varying asset consumption by individual products.

Traditional cost recording systems for costs allocated to cost centers (CC) by type show:

- Who - CC 034 - Purchasing Department, CC 025

- Plant Production Department, ...,

- On what - materials, wages, services, ...,

- How much - individual cost values entered into the books by type,

- When - period of cost entry into the books, incurred the costs, i.e. spent money in the enterprise. However, only answers to the following questions:

In what way are the costs incurred?

- What affects the costs and to what extent?

make it possible to look for more rational measures and utilize assets facilitating cost cuts.

In case of such products as milk or pigs for slaughter, managers in agricultural enterprises being aware of their constantly changing profitability (in some periods market prices also result in their production being unprofitable), look for possibilities to obtain complete and detailed information on actual total cost of a product in comparison with sales revenue.

Thus it is advisable to develop a model integrating operations and costs data in order to improve operations management, planning and budgeting, organization of operations and control (Nowak, et al., 2004; Śliwczyński, 2006).

\section{Assumptions for the development of a model}

As the primary principle for the design of the model it was assumed that it should reflect the flow of materials and information accompanying specific production processes, which means that it should identify all costs generated at each stage of such a process both in an agricultural enterprise and throughout the entire supply chain (from procurement, through agricultural production processes to distribution to the final customer or consumer). In view of this fact, an integral part of the input data base for the system comprises specially developed individual cards for each product, recording all actions (events) connected with the production of this product at all stages of this process, i.e. procurement, production and distribution. Figure 1 presents an example diagram of the product - process - actions - tasks - assets analysis based on records kept in the form of a model process card in an agricultural enterprise.

\section{Principles of operation for the in- tegration model of operations and cost data}

\subsection{Structure of the integration model of opera- tions and cost data}

Figure 2 presents a diagram of the model for identification, analysis and costing of product costs in agricultural enterprises not having an integrated ERP-class system.

In the operations data recording system processes, actions, tasks and assets (based on reference dictionaries) are defined for individual products in an agricultural enterprise, as well as relationships between products.

Figure 3 given below presents an example of a record of data for a plant product, i.e. wheat, which - apart from being sold - may also be used as a component in feed production. Thus farm fodder constitutes an intermediate product in animal production, but it may also be sold as a final product.

The operations data recording system includes also cropping area for individual plant products (in [ha]) with an allocated distance of cultivated fields of individual crops from the farming machinery base of the enterprise (in terms of transport distances in $[\mathrm{km}])$. Soil quality for individual cultivated areas is defined for the needs of soil fertilization and enrichment (varying action requirements). This is presented in Figure 4 in the form of a diagram.

In the recording system assets are allocated to tasks being realized (Table 2). 
Figure 1. An example of product - process - actions - tasks - assets analysis on the basis of records included in the process measurement sheet of an agricultural enterprise.

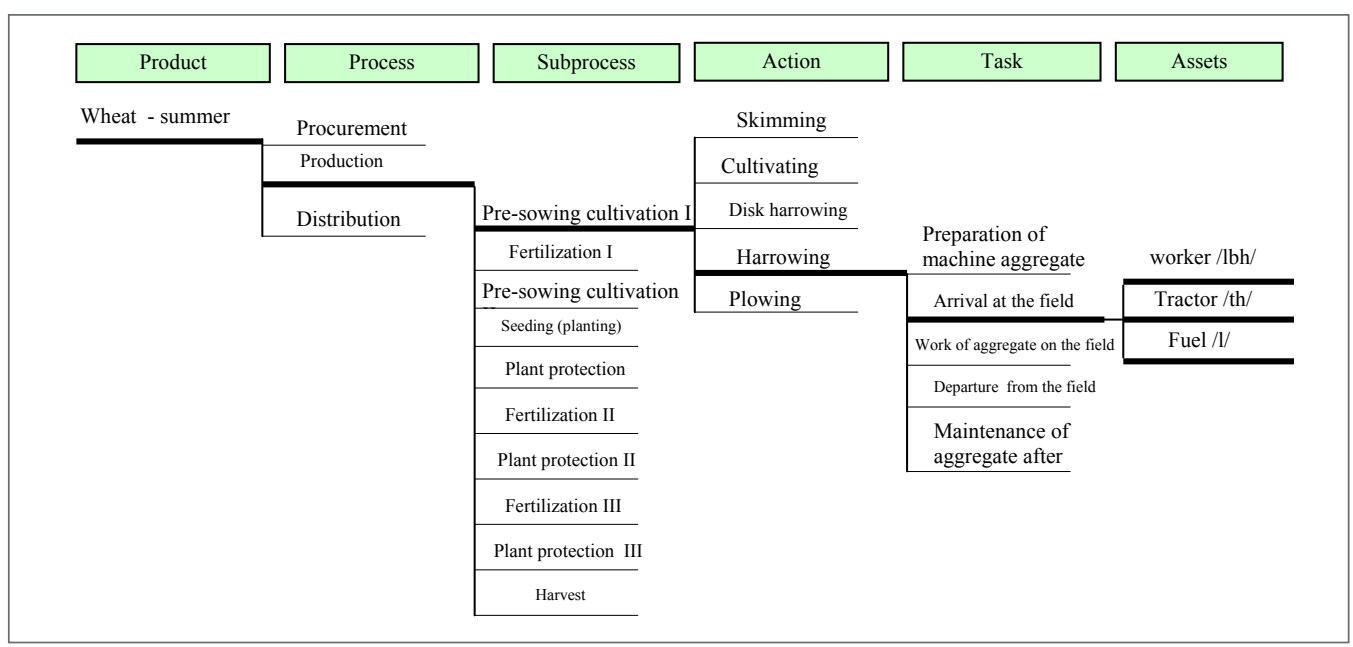

Source: study made on the basis of research of the Poznań University of Life Sciences and Institute of Logistics and Warehousing in Poznań.

Figure 2. Organization scheme of operational costs identification, analysis and costing system

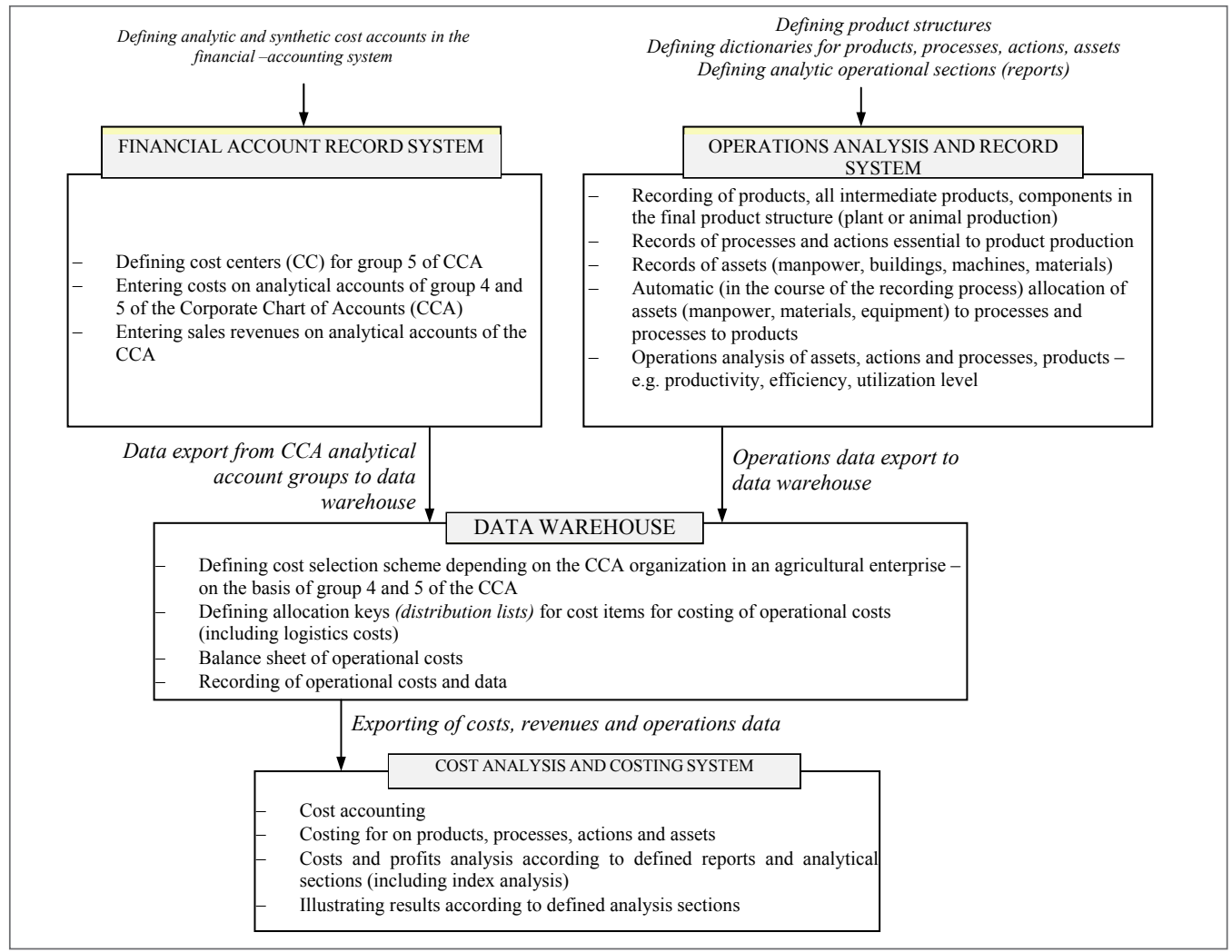


Figure 3. An example of a data record for product "Wheat".

\begin{tabular}{|c|c|c|c|c|}
\hline Product name & Completion time & Product level name & Level 0 element name & Unit of measurement \\
\hline e.g. fodder for cattle & July 2008 & intermediate product & Cattle for slaughter & $\mathrm{kg}$ \\
\hline Product ID & Product group & Product level number & Name of level 2 & Source of origin \\
\hline e.g. 0030270109 & Plant production & 1 & $\begin{array}{l}\text { wheat, component } 12 \text {, } \\
\text { component } 5\end{array}$ & Farm fodder production \\
\hline
\end{tabular}

Figure 4. A scheme of location recording for individual products.

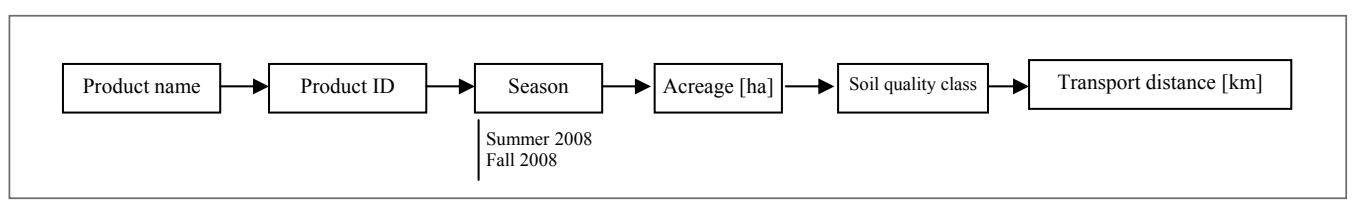

Table 2. An example of allocating assets to actions and consumption recording system

\begin{tabular}{|c|c|c|c|c|c|c|}
\hline Action & Asset type & $\begin{array}{l}\text { Asset name (model, } \\
\text { type) }\end{array}$ & $\begin{array}{l}\text { Asset } \\
\text { index }\end{array}$ & Unit & $\begin{array}{l}\text { Consumption } \\
\text { level }\end{array}$ & $\begin{array}{l}\text { Assets: } \\
\text { O-own } \\
\text { Out-outsourced }\end{array}$ \\
\hline \multirow{10}{*}{$\begin{array}{l}\text { Fertilizer sowing } \\
\text { process or foliar } \\
\text { application of fer- } \\
\text { tilizer }\end{array}$} & worker & Krzysztof Luniewski & & {$[\mathrm{lbh}]$} & & $\mathrm{O}$ \\
\hline & Fuel & E-95 & & [litr] & & O \\
\hline & $\begin{array}{l}\text { Means of } \\
\text { transport }\end{array}$ & Tractor CR-23 & & [th] & & $\mathrm{O}$ \\
\hline & $\begin{array}{l}\text { Material } \\
\text { (fertilizer) }\end{array}$ & Fertilizer JH5 & & [kg] or [litre] & & $\mathrm{O}$ \\
\hline & Machine & Fertilizer distributor & & {$[\mathrm{mh}]$} & & $\mathrm{O}$ \\
\hline & Machine & $\begin{array}{l}\text { Spraying machine } \\
\text { 0-45 }\end{array}$ & & {$[\mathrm{mh}]$} & & Out \\
\hline & Machine & Loader $Ł P 8$ & & {$[\mathrm{mh}]$} & & $\mathrm{O}$ \\
\hline & Machine & Water-cart B-2 & & {$[\mathrm{mh}]$} & & Out \\
\hline & Machine & $\begin{array}{l}\text { Cultivation aggre- } \\
\text { gate AU1 }\end{array}$ & & {$[\mathrm{mh}]$} & & 0 \\
\hline & Machine & $\begin{array}{l}\text { Seeding aggregate } \\
\text { AS9 }\end{array}$ & & {$[\mathrm{mh}]$} & & O \\
\hline
\end{tabular}


Aggregation of amounts and values of asset consumption per action attributed to individual processes in an agricultural enterprise facilitates calculation of asset consumption (labor and material consumption) in realized processes (Sierpińska and Niedbała, 2002). The recording system presented above makes it possible to attribute asset consumption to a product and after attributing costs to consumption values in case of individual assets this system makes it possible to analyze operational costs of individual processes and agricultural products.

In the proposed model integration of cost data entered in the financial-accounting system of an agricultural enterprise and operations data entered in the recording and operational analysis system is achieved through (Figure 2):
- clustering of cost data in cost centers (CC) attributed to the enterprise organization units, according to the organizational structure of this enterprise, - exporting of cost data to data warehouse from groups 4 and 5 of the CCA and sales data of the agricultural enterprise,

- exporting of operations data to the data warehouse,

- defining of a scheme of operational cost selection and cost item allocation keys,

- identification of operational costs and their costing per products, actions and operational assets.

Table 3 presents an example of cost recording in the financial-recording system of an agricultural enterprise, which is discussed below.

Table 3. An example of cost allocation for purchase of diesel oil to accounts of departments consuming the oil

\begin{tabular}{|l|l|l|l|l|l|l|l|l|} 
Accounting & $\begin{array}{l}\text { Date of } \\
\text { entry in } \\
\text { books }\end{array}$ & $\begin{array}{l}\text { Account } \\
\text { number } \\
\text { (group 4) }\end{array}$ & $\begin{array}{l}\text { Amount } \\
\text { Credit (4) }\end{array}$ & $\begin{array}{l}\text { Account } \\
\text { number(of } \\
\text { group 5) }\end{array}$ & $\begin{array}{l}\text { Amount } \\
\text { Debit (5) }\end{array}$ & $\begin{array}{l}\text { Cost } \\
\text { Centre } \\
\text { number }\end{array}$ & $\begin{array}{l}\text { Asset } \\
\text { index }\end{array}$ & Currency \\
\hline 2/08/PURCHASE & $2008-04-23$ & $411-07-07-1$ & 1000.00 & $501-02$ & 700.00 & 1 & ON-1 & PLN \\
\hline 2/08/PURCHASE & $2008-04-23$ & $411-07-07-1$ & 1000.00 & $503-03$ & 300.00 & 1 & ON-1 & PLN \\
\hline
\end{tabular}

Purchase of diesel oil is entered on account 411-0707-1 (costs by type). This purchase item was entered with accounting identifier 2/08/PURCHASE - generated on the basis of the accounting log number, partial log name and accounting document number. Account 411-07-07-1 is a subordinate account in the group of accounts 411-07, defined for entering the purchase of diesel oil and it refers to one of the plants (Plant 1) within this agricultural enterprise - a business unit from $\mathrm{CC}=1$. Plant 1 , apart from its primary activity (account 501-02) runs also repair activity (account 502-01), supervision activity (account 503-03), auxiliary production (account 504-02) and accommodation services (account 507-02). For the purpose of cost data ordering and analysis, data export periods from the financial-accounting system to the data warehouse were defined as e.g. daily, weekly, 10-day and monthly.

In the data warehouse a scheme of operational costs selection in an agricultural enterprise is defined on the basis of group 4 of accounts (costs entered by type) and group 5 of accounts (costs entered by function and costing category), depending on the organization of the CCA of this agricultural enterprise and the required analyses of analytical account contents. Attributing costs to assets is the basis of recording in group 4 of the CCA, because entering costs by type is entering costs by assets (Kaplan and Atkinson,1992) - e.g. tangible assets depreciation costs, wages, materials, traveling expenses, etc. For the example presented above, purchase cost of diesel oil (entered on account 411-07-07-1) will be treated entirely as an operational cost. However, only the part distributed to account 501-02 (700.00 PLN) will be the basis for operational analysis of primary production in order to determine the part of the cost to be qualified as production cost. The rest of the cost related to the purchase of diesel oil distributed to account 503-03, designated for supervision activity, is treated entirely as an intermediate general cost (IC), outside production operational costs.

Further operational analysis of fuel consumption in primary activity (account 501-02) requires the identi- 
fication of the share of fuel consumption per primary operational actions - e.g. harrowing includes - arrival at the field, harrowing, return from the filed. In order to obtain a more detailed cost analysis and exclude logistics costs, only fuel consumption within arrival at the field and return is an operational cost of logistics and diesel oil consumption within harrowing is an operational cost of production.

\subsection{Export of operations data to the data ware- house}

Operational records run by workers or their immediate managers (master workmen, foremen) each time refer to assets consumption in the process of realizing individual tasks. This leads to the creation of a work $\log$ in an agricultural enterprise, comprising the following information:

- worker X sprayed potatoes,

- spraying machine O-45 was used to do the spraying,

- 25 liters of preparation W-23 were used to spray 2.5 ha of the potato filed,

- tractor CR-23 was used for transport to and from the field and in the course of spraying.

The data record in the recording and operational analysis system, at the same time being the export data record to the data warehouse, takes the form presented in Table 4.

Table 4. Algorithm of the asset-action-subprocess-process-product data record in the operational recording system

\begin{tabular}{|l|l|l|l|l|l|l|l|l|l|l|}
\hline $\begin{array}{l}\text { Date of } \\
\text { execu- } \\
\text { tion }\end{array}$ & $\begin{array}{l}\text { Asset } \\
\text { name }\end{array}$ & $\begin{array}{l}\text { Asset } \\
\text { index }\end{array}$ & $\begin{array}{l}\text { Asset } \\
\text { unit }\end{array}$ & $\begin{array}{l}\text { Con- } \\
\text { sump- } \\
\text { tion } \\
\text { level }\end{array}$ & Task & $\begin{array}{l}\text { Date / } \\
\text { Dura- } \\
\text { tion }\end{array}$ \\
\hline
\end{tabular}

Source: own study.

Definite attribution of products to processes (leading to their production) as well as assets used in realized tasks makes it possible to determine the relationship between the quantity of agricultural products produced and the level of asset consumption.

\subsection{Operations of selection and data ordering in the data warehouse}

The first action in the data warehouse with reference to the data exported from the financial-accounting system is to define the scheme of costs selection depending on the organization of the CCA in the agricultural enterprise on the basis of groups 4 and 5 of the CCA. This stage is important due to the attribution of accounting items to operational costs (OC). In the presented example the entered items receive indicators as a result of selection, as it is presented in table 5 .

Table 5. An example of cost type indicator allocation after settling of one analytical account of group 4 (costs by type) to two analytical accounts of group 5 (costs by costing nature). An example of integration of operations data: one asset different actions

\begin{tabular}{|l|l|l|l|l|l|l|l|l|l|}
\hline $\begin{array}{l}\text { Accounting } \\
\text { identifier }\end{array}$ & $\begin{array}{l}\text { Date of } \\
\text { entry in } \\
\text { books }\end{array}$ & $\begin{array}{l}\text { Account } \\
\text { number } \\
\text { (group 4) }\end{array}$ & $\begin{array}{l}\text { Amount } \\
\text { Credit } \\
\mathbf{( 4 )}\end{array}$ & $\begin{array}{l}\text { Account } \\
\text { number (of } \\
\text { group 5) }\end{array}$ & $\begin{array}{l}\text { Amount } \\
\text { Debit } \\
\mathbf{( 5 )}\end{array}$ & $\begin{array}{l}\text { Cost } \\
\text { Centre } \\
\text { number }\end{array}$ & $\begin{array}{l}\text { Asset } \\
\text { index }\end{array}$ & $\begin{array}{l}\text { Currency } \\
\text { t2/08/PURCHASE } \\
\text { indicator }\end{array}$ \\
\hline 12/08/PURCHASE & $2008-04-23$ & $\begin{array}{l}411-07- \\
07-1\end{array}$ & 1000.00 & $501-02$ & 700.00 & 1 & ON-1 & PLN & OC \\
\hline
\end{tabular}


In turn, Table 6 presents another example, i.e. the purchase of pesticides entered on account 411-06, in the amount of PLN 3560.00. This item is entered as a cost of three different plants (Plant $1-\mathrm{CC}=1$, Plant 3 - CC $=3$, Plant $4-\mathrm{CC}=4)$. In each plant this cost is distrib- uted to primary activity (account 501-02). Consumption of pesticides is an operational cost of production hence the following operational cost indicators will be attributed to accounting items in the data warehouse.

Table 6. An example of allocation of a cost type identifier to different types of costs entered on several analytical accounts of group 4 (costs by type) to one analytical account of group 5 (costs by costing nature). An example of integration of operations data: many assets - one action

\begin{tabular}{|l|l|l|l|l|l|l|l|l|l|} 
Accounting & $\begin{array}{l}\text { Date of } \\
\text { entry in } \\
\text { books }\end{array}$ & $\begin{array}{l}\text { Account } \\
\text { number } \\
\text { (group 4) }\end{array}$ & $\begin{array}{l}\text { Amount } \\
\text { Credit (4) }\end{array}$ & $\begin{array}{l}\text { Account } \\
\text { number (of } \\
\text { group 5) }\end{array}$ & $\begin{array}{l}\text { Amount } \\
\text { Debit (5) }\end{array}$ & $\begin{array}{l}\text { Cost } \\
\text { Centre } \\
\text { number }\end{array}$ & $\begin{array}{l}\text { Asset } \\
\text { index }\end{array}$ & $\begin{array}{l}\text { Currency } \\
\text { type } \\
\text { indicator }\end{array}$ \\
\hline 7/08/PURCHASE & $2008-02-12$ & $411-06-06-1$ & 1500.00 & $501-02$ & 1500.00 & 1 & SOR-12 & PLN & OC \\
\hline 7/08/PURCHASE & $2008-02-12$ & $411-06-06-3$ & 1240.00 & $501-02$ & 1240.00 & 3 & SOR-12 & PLN & OC \\
\hline 7/08/PURCHASE & $2008-02-12$ & $411-06-06-4$ & 820.00 & $501-02$ & 820.00 & 4 & SOR-12 & PLN & OC \\
\hline
\end{tabular}

Source: own study.

Assets identification, definite for both recording systems, is a prerequisite for cost and operations data integration. On one hand, tasks (within actions, subprocesses and processes) are realized with the use of assets and on the other hand, costs related to assets consumption are incurred.

Two recording systems presented below facilitate cost analysis of operational actions, making it pos- sible to determine when and in what actions, as well as for which products individual assets were used and what costs are entered to debit the account of the assets used.

A relation between operations and cost data is presented in the form of a diagram in Figure 5.

Figure 5. The connection of operations and accounting data in the proposed model

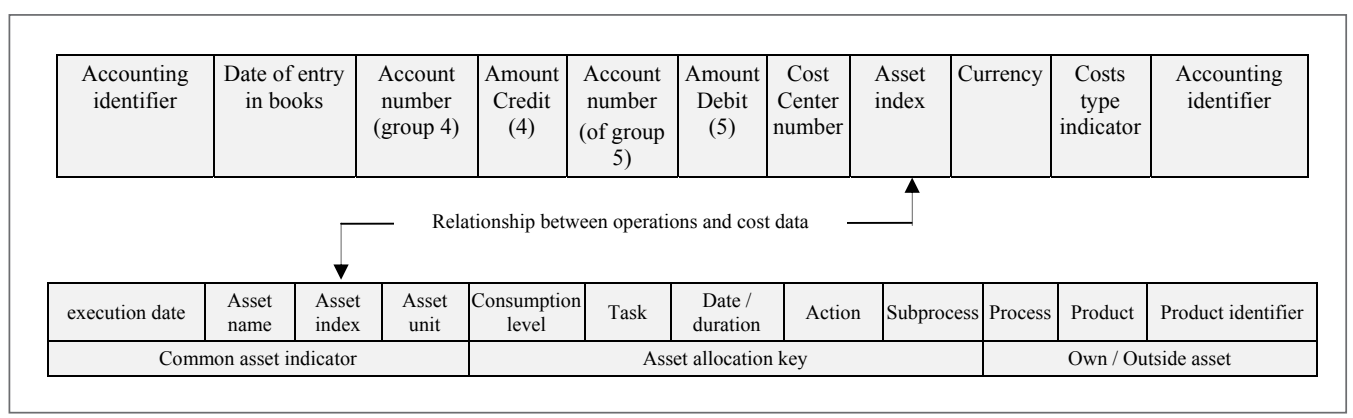

Source: own study 
All cost data exported from the financial-accounting system of an agricultural enterprise and operations data exported from the recording and operational analysis system are archived in the data warehouse.

Analysis of the share of operational costs in the total cost of a product or process of its production is an important element of controlling in terms of operational costs management and controlling profitability of an agricultural enterprise (Novack and Simco, 1991). Analysis of cost location, level and dynamics constitutes the basis for an adequate preparation of the offered product range as well as processes and resources in the supply chain of agricultural products.

The share of operational costs in the production of agricultural products (plant and animal products and services) obtained on costing is usually calculated per physical unit of measurement of the product (piece, kilogram, ton, liter). In a very commonly known example when agricultural enterprises produce a wide range of products (of plant and animal origin) as well as services and the products within the same product group require similar expenditure (e.g. cereals and root crops in massscale production), then the share of operational costs is obtained as a result of process costing - as an average cost. This calculation is based on cost data, related to the value of incurred costs, and operations data, related to the quantity of products produced and processes realized in the assumed unit of measurement. Costing in case of operational costs per any cost carrier - product, process, action - requires a precise cost identification and identification of the share of individual assets, for which costs were incurred. Calculation of all costs per product, process or action results from costs of all assets used, as it is presented in Figure 6.

Table 7 presents an example of consumption of 175 liters of diesel oil ON-1 at the unit price of PLN 4.00, amounting to the cost of PLN 700.00, distributed to operational actions to account 501-02.

Figure 6. Organizational scheme of data relationships in the process of costing per product

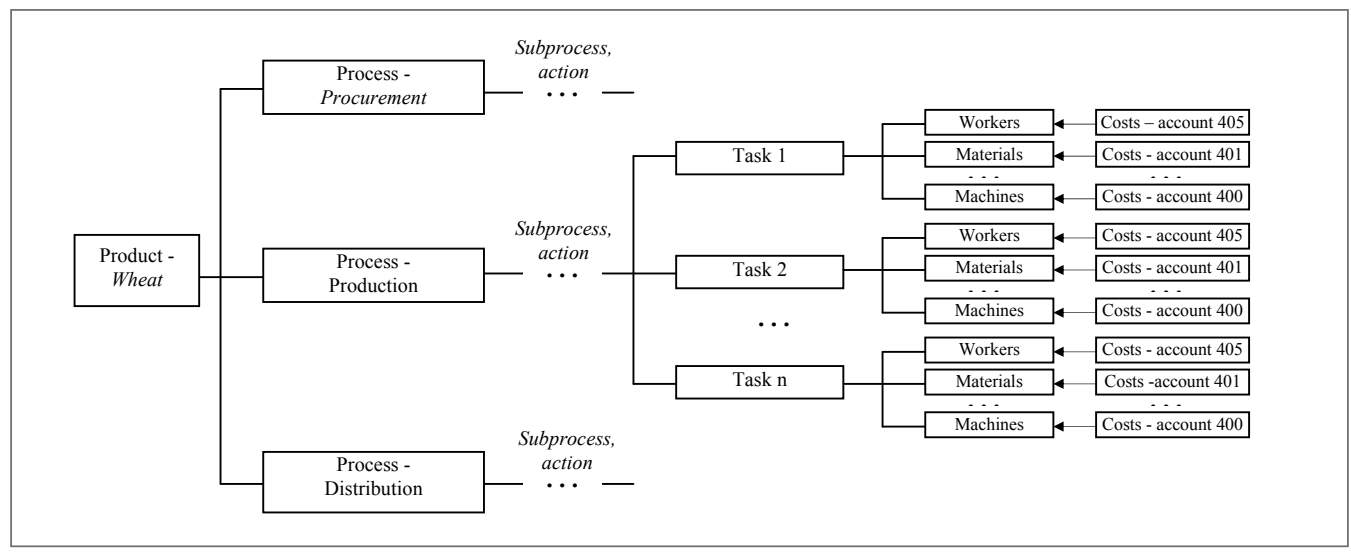

Table 7. An example of allocation of diesel oil consumption to operation actions

\begin{tabular}{|c|c|c|c|c|c|c|c|c|c|c|c|}
\hline $\begin{array}{l}\text { Accounting } \\
\text { identifier }\end{array}$ & $\begin{array}{l}\text { Date of } \\
\text { entry in } \\
\text { books }\end{array}$ & $\begin{array}{l}\text { Account } \\
\text { number } \\
\text { (group } \\
\text { 4) }\end{array}$ & $\begin{array}{l}\text { Amount } \\
\text { Credit } \\
(4)\end{array}$ & $\begin{array}{l}\text { Account } \\
\text { number } \\
\text { (of } \\
\text { group 5) }\end{array}$ & $\begin{array}{l}\text { Amount } \\
\text { Debit } \\
(5)\end{array}$ & $\begin{array}{l}\text { Cost } \\
\text { Centre } \\
\text { number }\end{array}$ & $\begin{array}{l}\text { Asset } \\
\text { index }\end{array}$ & $\begin{array}{l}\text { Amount } \\
\text { [liters] }\end{array}$ & $\begin{array}{l}\text { Unit } \\
\text { value }\end{array}$ & Currency & $\begin{array}{l}\text { Cost type } \\
\text { indicator }\end{array}$ \\
\hline $\begin{array}{l}\text { 12/08/ } \\
\text { PURCHASE }\end{array}$ & $\begin{array}{l}2008-04- \\
23\end{array}$ & $\begin{array}{l}411-07- \\
07-1\end{array}$ & 1000,00 & 501-02 & 700,00 & 1 & ON-1 & 175 & 4.00 & PLN & $O C$ \\
\hline
\end{tabular}


Figure 7. An example of costing for diesel oil ON-1 consumption per harrowing

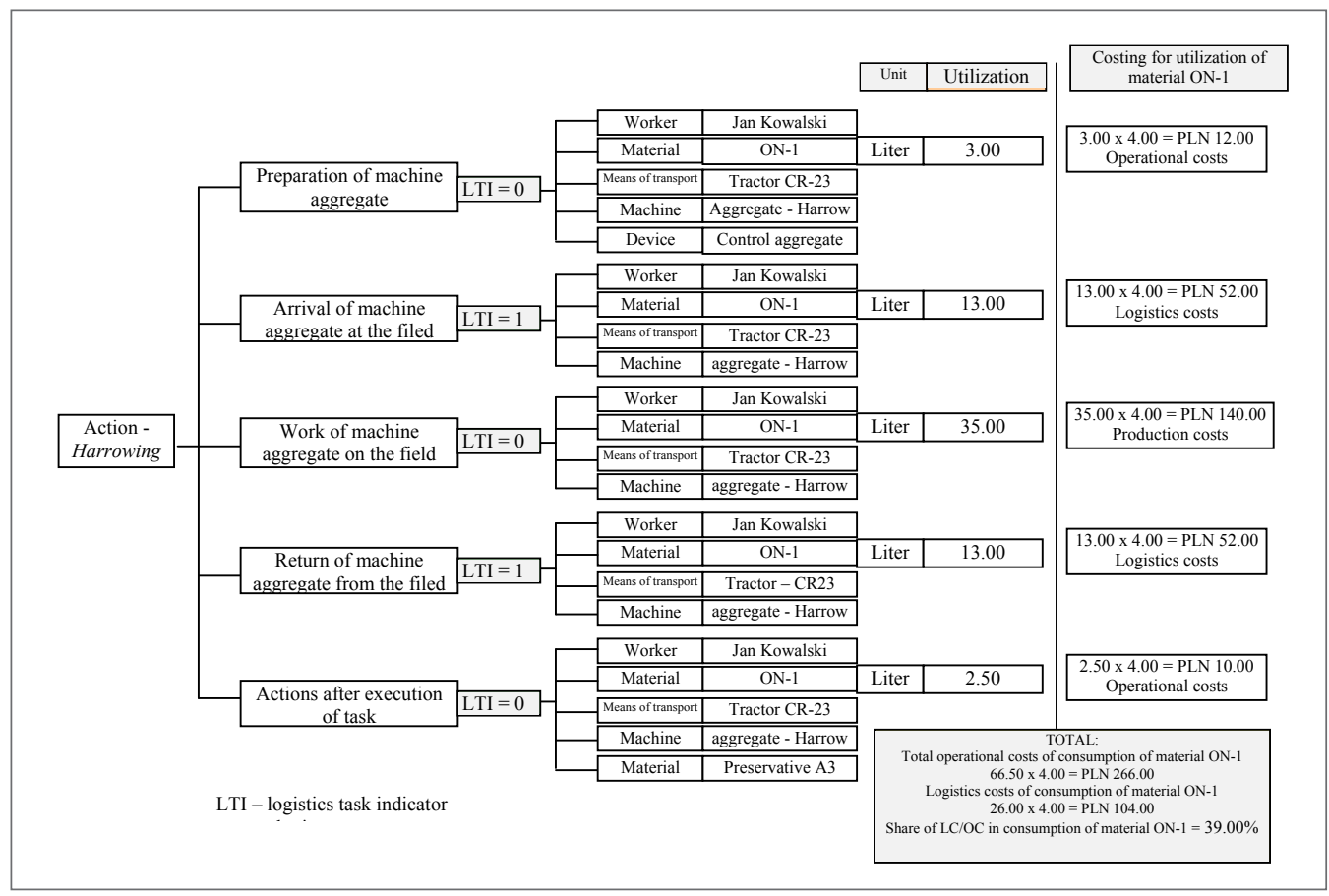

Source: own study

Costs of the other assets related to harrowing are calculated in the IT system in a similar way and next costing is performed for all actions, yielding costs of subprocesses and processes in order to obtain the resulting calculation of costs per product. If diesel oil ON-1 was stored in tanks before use, the collection of a particular amount of oil from the warehouse results in the calculation of inventory maintenance costs for oil (including warehousing costs and financial costs of frozen capital) per the number of units consumed (liters), thus increasing the unit value of the warehousing process product (e.g. from PLN 4.00 / Liter to PLN 4.08 / Liter).

\section{Conclusions}

Cost analysis is used in many fields to assess the activity of an agricultural enterprise (e.g. for the needs of the Report for the financial year related to economic and financial activity of an agricultural enterprise). The results of cost analysis are used to improve operational managing processes, in planning and budgeting, in activity and control (Argyris and Kaplan, 1994). Cost analytical sections, by means of the cost account method used, make it possible to determine (Cooper and Kaplan, 1991):

- the relationship, dynamics and cost structure in terms of the realized actions, operational processes (including logistics ones) and products,

- the relationship between costs and assets consumed, the inventory maintained, the materials used and the methods of work,

- the allocation of costs per products and processes as well as cost centers,

- the multidimensional dependence of profit (distributed to individual products) on incurred costs.

Besides, such a structure of the proposed information system model for the identification and analysis of logistics costs for agricultural enterprises will make it possible to:

- estimate the level and structure of logistics costs and their influence on the whole farm activity,

- identify the diversity of costs and profitability, being a result of supplying various products and logistics services to particular consumers,

- identify changes in total costs and farm profitability 
caused by decisions concerning consumer and product category or distribution channels; indicate factors shaping the level and structure of logistics costs,

- characterize the influence of behavior of participants of the supply chain (consumers and suppliers) on costs and farm profitability; point at possibilities to reduce logistics costs,

- increase quality, efficiency or rate of particular activities and whole logistics processes in a permanent or temporary way,

- in view of the above such model could be a valuable tool assisting the management process in this type of enterprise.

In view of the above such model could be a valuable tool assisting the management process in this type of enterprise.

\section{References}

1. Argyris C., Kaplan R. S., 1994. Implementing New Knowledge: The Case of Activity-Based Costing. Accounting Horizons, September: 83-105.

2. Barney J.B., 1991. Firm resources and sustained competitive advantage. Journal of Management. Vol. 12, 99-120.

3. Christopher M., Logistics and Supply Chain Management, Prentice Hall, New York 2005.

4. Cooper R., Kaplan R. S., 1991. Profit Priorities from Activity-Based Costing. Harvard Business Review. May/June:130-135.

5. Horvath P., Controlling, München 1990.

6. Kaplan R.S., Atkinson A.A., Advanced Management Accounting, Prentice-Hall, New York 1992.

7. Kaplan R.S., Cooper R., 1988. Measure Costs Right; Make the Right Decisions. Harvard Business Review, September/October :96-103.

8. Kaplan R.S., Norton D.P., 2001. The Strategy Focused Organization. How Balanced Score-card Companies Thrive in the New Business Environment, Harvard Business School Press, Boston Massachusetts.

9. Nita B., Rachunkowość w zarządzaniu strategicznym przedsiębiorstwem, Wolters Kluwer Polska Sp. z o.o. Kraków 2008 .

10. Novack R.A., Simco S.W., 1991. The industrial procurement process. Journal of Business Logistics, 12 No.1:145-165.

11. Nowak E., Piechota R., Wierzbiński M., Rachunek kosztów w zarządzaniu przedsiębiorstwem. Polskie Wydawnictwo Ekonomiczne, Warszawa 2004.

12. Pfohl H.Ch., Systemy logistyczne. Podstawy organizacji i zarządzania. IliM, Poznań 1998.

13. Rzymyszkiewicz E., Transportochłonność w działalności logistycznej przedsiębiorstw. Logistyka nr 2, 1995.

14. Skowronek Cz., Sarjusz-Wolski Z., Logistyka w przedsiębiorstwie, Wydanie 4, PWE, Warszawa 2007.

15. Sierpińska M., Niedbała B., Controlling operacyjny w przedsiębiorstwie. Wydawnictwo Naukowe PWN, Warszawa 2002.

16. Śliwczyński B., Controlling w zarządzaniu logistyka. Wyższa Szkoła Logistyki. Poznań 2007.

17. Śliwczyński B., Controlling w łańcuchu dostaw skutecznym narzędziem budowania przewagi konkurencyjnej, Instytut Logistyki i Magazynowania, Poznań 2006.

18. Wajszczuk K., Wielicki W., The level and structure of logistics costs in great area agricultural enterprises. Roczniki AR Poznań, CCCLIX, Ekon.3, 2004.

19. Vollmuth H., Controlling - instrumenty od A do Z, Wydawnictwo Placet, Warszawa 1995.

20. Wajszczuk K., Transportochłonność produkcji roślinnej w wielkopolskich gospodarstwach indywidualnych. Problemy Inżynierii Rolnej, Nr. 1, 1994.

21. Wajszczuk K., Logistics costs analysis as an assisting tool to achieve competitive advantage for agricultural enterprises, 11th International Congress of the EAAE "The Future of Rural Europe in the Global Agri-Food System", Copenhagen, Denmark: August 24-27, 2005 Paper available on CD and on the Internet at www.eaae2005.dk/scientificprogramme.htm

22. Wielicki W., 1983. Transportochłonność produkcji rolniczej. Roczniki Nauk Rolnych, Series C-76-1, 1983.

23. Wolszczan J.,1988. Transportochłonność rolnictwa. Zeszyty Probl. Post. Nauk Rol., 348, 1988.

\section{Acknowledgements}

The paper is funded by the research budget within the scientific project for 2007-2010 No:R11 00902 